\title{
THE POSSIBILITY OF USING FILAMENTOUS FUNGUS IN THE TECHNOLOGY OF THE FORMATION OF HIGHLY POROUS SURFACES ON BIOCOMPATIBLE SUBSTANCES
}

\author{
M.O. Vorobets, V.V. Strebezhev \\ Department of Physics of Semiconductor and Nanostructures, \\ Chernivtsi National University, 2 Kotsubynsky Str., Chernivtsi 58012, Ukraine \\ e-mail:maxver@i.ua
}

This work reports the possibility of using fungal mycelium to form the highly porous surfaces of biocompatible substances by the example of calcium acetate. The main aim of the work was the search of conditions for forming of porous structures from the volatile molecules of calcium acetate on microscopic filaments of fungal mycelium and the study of the surfaces formed from calcium acetate. Highly porous surfaces were formed by the condensation of volatile calcium acetate molecules on the fungal mycelium during vegetative development under condition close to room temperature. Various conditions allow the mean pore size of the surface of calcium acetate to range from $25 \div 50 \mu \mathrm{m}$. Experiment shows that the using of the natural structure of fungal mycelium as the filamentous substratum for condensation of the solid highly porous formations of calcium acetate can change the porousness of our samples and vary the use of these biocompatible materials in different spheres.

Keywords: biocompatible substances, highly porous surfaces.

\section{Introduction}

Compounds based on biocompatible substances are promising materials for implants, absorbers and microscopic materials in medicine. The highly porous formations of calcium acetate are structures with good prospects for manufacture of bioceramics [1, 2]. Calcium phosphate is one of the bioceramic materials which are used in treatment of bone tissues [3, 4]. $\mathrm{Ca}_{3}\left(\mathrm{PO}_{4}\right)_{2}$ arises by heating of the calcium acetate samples by the vapor of phosphorus oxide and keeps the capillary porous structure of the initial sample [5, 6]. Therefore, a search of methods to change porosity is a very important task.

The fungal mycelium is an example of the natural micro- and nanostructure [7]. Hence, the employment of vegetative mycelium as microstructural substrate for synthesis of highly dispersed systems is a very perspective proposition.

We report in this work the possible employment of fungal mycelium for highly porous surface formations of biocompatible substances such as calcium acetate. The purpose of this work was to investigate the surface formation of calcium acetate.

\section{Experimental}

The highly porous surface formations were created by condensation of the volatile molecules of calcium acetate from atmosphere over its aqueous solution on mycelium of the fungus Aspergillus in the process of vegetative development under near room temperature conditions. Then the porous surfaces of calcium acetate were observed by optical microscope. 
The aqueous solution of calcium acetate was created by interaction between calcium carbonate and acetic acid according to following chemical equation:

$$
\mathrm{CaCO}_{3}+2 \mathrm{CH}_{3} \mathrm{COOH}=\left(\mathrm{CH}_{3} \mathrm{COO}\right)_{2} \mathrm{Ca}+\mathrm{H}_{2} \mathrm{O}+\mathrm{CO}_{2}
$$

Obtained aqueous solution of calcium acetate represent a fait sour taste with hydrogen ion exponent $\mathrm{pH}=6$. Due to the rest of calcium carbonate in aqueous solution there are plenty of $\mathrm{Ca}^{2+}$ ions and the hydrogen ion exponent increases in range of $6<\mathrm{pH}<8$.

The aqueous solution of calcium acetate was placed in a glass vessel to one-fourth of the volume. Glass plates with micelles of the fungus Aspergillus were placed in empty threefourths of the vessel above aqueous solution where air circulated freely. Air with the volatile molecules of calcium acetate could circulate in the system. For the creation of temperature conditions the vessel with solution was placed in a thermostat. There were conditions for forming porous structures from the volatile molecules of calcium acetate on microscopic filaments of fungal mycelium.

Obtained solid surfaces of calcium acetate have the dendritic capillary porous structure. By changing the conditions of condensation of volatile molecules it is possible to change the porosity of surfaces of calcium acetate. The capillary porous structure of the samples permits the carrying out of absorption of anions of phosphorus acids by heating them in the penetrative vapors of phosphorus oxide for manufacture of the porous surface formations of bioceramics:

$$
\left(\mathrm{CH}_{3} \mathrm{COO}\right)_{2} \mathrm{Ca}+2 \mathrm{PO}_{4}=6 \mathrm{CH}_{3} \mathrm{COO}+\mathrm{Ca}_{3} \mathrm{O}\left(\mathrm{PO}_{4}\right)_{2} .
$$

\section{Result and discussion}

In this paper, we report the result of the first researches of the highly porous surface formations of calcium acetate on fungal mycelium. The porosity of surfaces of calcium acetate was determined from its micrography (Fig. 1). From the observation it is follows that the pores in the surfaces of calcium acetate were different sizes in the ranging from 1 to 100 $\mu \mathrm{m}$ (Fig. 2). Different temperature conditions open the possibility of changing of porousness (Table). The mean size of the pores changes due to different temperature of condensation. In particular, by the increasing of temperature from 296 to $300 \mathrm{~K}$ the mean size of the pores increases from 42 to $50 \mu \mathrm{m}$. Since the rate of circulation of air does not significantly change the growth of the average pore size associated with the acceleration of biological processes of vegetative development of the fungal mycelium.

Surplus of ions of $\mathrm{Ca}^{2+}$ in aqueous solution was determined by the $\mathrm{pH}$ exponent. It appears, that in default of surplus of ions of $\mathrm{Ca}^{2+}$ at $\mathrm{pH}=6$, the mean size of the pores of calcium acetate is permanent at all condensations times. At growth of the hydrogen ion exponent to $\mathrm{pH}=8$ there is the gradual diminishing of mean size of the pores on the surfaces during time of condensation (Fig. 3). This change can be explained by the halt of vegetative development of fungal mycelium, which conforms to information [7] in obedience to which intensity of development of most fungi is maximal in a poorly sour environment at $\mathrm{pH}=5.3 \div 6.8$. This behavior opens the possibility of changing of the mean size of the pores in the surface of calcium acetate in range $25 \div 50 \mu \mathrm{m}$ and depend on time of condensation from 50 to 300 hours (Fig. 3). 


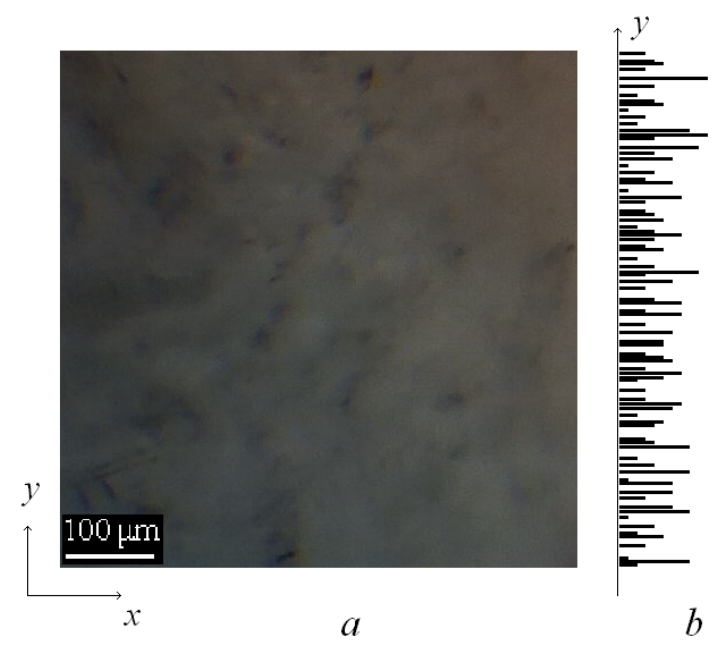

Fig. 1. Image of the porous surface of calcium acetate at $T=298 \mathrm{~K}$ (a) and the projection of centres of the pores on the $y$-axis with means of the characteristic size of the pores in the $x$-axis direction.

Table. Temperature dependence of the mean size of the pores in the surfaces of calcium acetate

\begin{tabular}{|c|c|c|c|c|c|}
\hline Temperature, K & 296 & 297 & 298 & 399 & 300 \\
\hline $\begin{array}{c}\text { The mean size } \\
\text { of the pores, } \\
\boldsymbol{\mu m}\end{array}$ & 42 & 43 & 45 & 48 & 50 \\
\hline
\end{tabular}

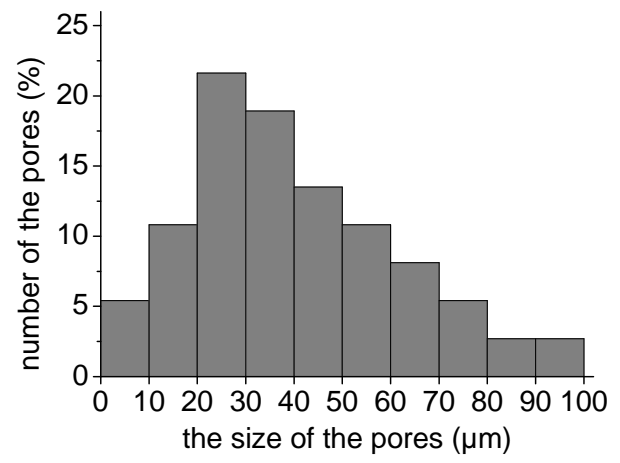

Fig. 2. Distribution of the size of the pores in the surface of calcium acetate at $T=298 \mathrm{~K}$.

\section{Conclusions}

Experiment shows that the using of the natural structure of fungal mycelium as the filamentous substratum for condensation of the solid highly porous formations of calcium acetate can change the porousness of our samples and vary the use of these biocompatible materials in different spheres. Obtained solid surfaces of calcium acetate have the dendritic capillary porous structure. By changing the conditions of condensation of volatile molecules it is possible to change the porosity of surfaces of calcium acetate. The mean size of the pores changes due to different temperature of condensation. The capillary porous structure of the samples permits the carrying out of absorption of anions of phosphorus acids by heating them in the penetrative vapors of phosphorus oxide for manufacture of the porous surface formations of bioceramics. 


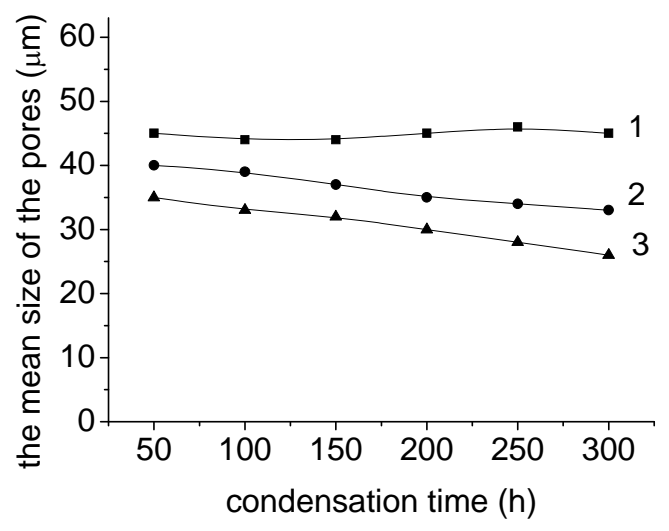

Fig. 3. The mean size of the pores in the surfaces of calcium acetate as dependent on condensation time at $T=298 \mathrm{~K}$ and different $\mathrm{pH}$ exponent in aqueous solution of calcium acetate: $1-\mathrm{pH}=6 ; 2-\mathrm{pH}=7 ; 3-\mathrm{pH}=8$.

\section{References}

1. Rivrak N., Tas A.C. Synthesis of calcium hydroxyapatite-tricalcium phosphate (HATCP) composite bioceramic powders and their sintering behavior. J. Am. Ceram. Soc. 1998. 81(9): 2245.

2. Raynaud S., Champion E., Bemache-Assolant D., Thomas P. Calcium phosphate apatites with variable $\mathrm{Ca} / \mathrm{P}$ atomic ratio. Biomaterials. 2002. 23(1): 1065.

3. Boner H. Calcium orthophosphates in medicine. Injury. 2001. 10 (1): S114.

4. Hench L.L. Bioceramics: from concept to clinic. J. Amer. Ceram. Soc. 1991. 74(1): 1487.

5. Hench L.L. Bioceramics. Amer. Ceram. Soc. 1998. 81 (1): 1705.

6. Elliot J.C. Structure and Chemistry of the apatites and other calcium orthophosphates. Elsevier. 1994. 18(1): 404.

7. Gapta S., Sharma K., Sharma R. Myconanotechnology and application of nanoparticles in biology. Rec. Res. Sci. Technol. 2012. 4(8): 36.

\section{REFERENCES}

1. Rivrak N., Tas A.C. Synthesis of calcium hydroxyapatite-tricalcium phosphate (HATCP) composite bioceramic powders and their sintering behavior. J. Am. Ceram. Soc. 1998. 81(9): 2245.

2. Raynaud S., Champion E., Bemache-Assolant D., Thomas P. Calcium phosphate apatites with variable $\mathrm{Ca} / \mathrm{P}$ atomic ratio. Biomaterials. 2002. 23(1): 1065 .

3. Boner H. Calcium orthophosphates in medicine. Injury. 2001. 10(1): S114.

4. Hench L.L. Bioceramics: from concept to clinic. J. Am. Ceram. Soc. 1991. 74(1): 1487.

5. Hench L.L. Bioceramics. Am. Ceram. Soc. 1998. 81(1): 1705.

6. Elliot J.C. Structure and Chemistry of the apatites and other calcium orthophosphates. Elsevier. 1994. 18(1): 404.

7. Gapta S., Sharma K., Sharma R. Myconanotechnology and application of nanoparticles in biology. Rec. Res. Sci. Technol. 2012. 4(8): 36. 


\title{
ЩОДО МОЖЛИВОСТІ ВИКОРИСТАННЯ НИТЧАСТИХ ГРИБІВ У ТЕХНОЛОГІЇ СТВОРЕННЯ ВИСОКОПОРИСТИХ ПОВЕРХОНЬ НА БІОСУМІСНИХ РЕЧОВИНАХ
}

\author{
М.О. Воробець, В.В. Стрєбєжєв \\ Кафедра фізики напівпровідників і наноструктур, \\ Чернівецький наџіональний университет імені Юрія Федьковича, \\ вул. Коиююбинського, 2, Чернівйі 58012, Україна, тахvеr@i.иа
}

\begin{abstract}
У даній роботі повідомляється про можливість використання міцелію грибів для формування високопористих поверхонь біосумісних речовин на прикладі ацетату кальиію. Головною метою роботи був пошук умов формування пористих структур 3 летких молекул ацетату кальиіюю на мікроскопічних нитках грибного міцелію та дослідження поверхонь, утворених з ацетату кальцію. Високопористі поверхні формувалися конденсацією летких молекул ацетату кальиію на міџелії грибів у процесі вегетативного розвитку при близьких до кімнатної температури умовах. Різні умови дозволяють змінювати середній розмір пор поверхні ацетату кальиію в діапазоні $25 \div 50$ мкм. Експеримент показую, що використання природної структури грибного міцелію як волокнистої основи для конденсації твердих високопористих утворень ацетату кальцію може змінювати пористість наших зразків та урізноманітнити використання біосумісних матеріалів у різних сферах.
\end{abstract}

Ключові слова: біосумісні речовини, високопористі поверхні

\section{О ВОЗМОЖНОСТИ ИСПОЛЬЗОВАНИЯ НИТЧАТЫХ ГРИБОВ В ТЕХНОЛОГИИ ФОРМИРОВАНИЯ ВЫСОКОПОРИСТЫХ ПОВЕРХНОСТЕЙ НА БИОСОВМЕСТИМЫХ ВЕЩЕСТВАХ}

\author{
М.О. Воробец, В.В. Стребежев \\ Кафедра физики полупроводников и наноструктур, \\ Черновиџкий наџиональный университет имени Юрия Федьковича, \\ ул. Коиююбинкого, 2, Черновиь 58012, Украина, тахvеr@i.иа
}

В данной работе сообщается о возможности использования мицелия грибов для формирования высокопористых поверхностей биосовместимых веществ на примере ащетата кальция. Главной целью работы был поиск условий формирования пористых структур из летучих молекул ацетата кальчия на микроскопических нитках грибного мицелия и исследование поверхностей, образованных из ацетата кальция. Высокопористые поверхности формировались конденсацией летучих молекул ацетата кальция на мицелии грибов в процессе вегетативного развития при близких к комнатной температуре условиях. Разные условия

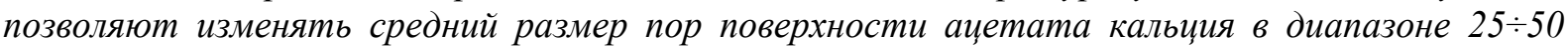
мкм. Эксперимент показывает, что использование природной структуры грибного мицелия как волокнистой основы для конденсации твёрдых высокопористых образований ацетата кальиия может изменять пористость наших образиов и варьировать использование биосовместимых материалов в разных сферах.

Ключевые слова: биосовместимые вещества, высокопористые поверхности 